\title{
Studies on the Effect of Effluent Discharge into Two Different Rivers Located In Abia and Imo State, Nigeria.
}

\author{
Okoronkwo, C. $\mathrm{U}^{1}$, And Nwachukwu, N.O ${ }^{2}$ \\ Department Of Food Microbiology Abia State University, Uturu, Abia State,Nigeria.
}

\begin{abstract}
The effects of effluent discharge into two different stream (Nkuho and Nworie stream) in Abia and Imo State were evaluated by collecting sample in different designated stations of the rivers. Physicochemical analysis revielled the level of temperature, $\mathrm{pH}$, turbidity dissolved oxygen, biochemical oxygen demand, chemical oxygen demand, mercury, lead, and copper of the river water. Samples were taken from coca-cola, Saclux paint, upstream, downstream, point of effluent discharge respectively. The results reveled significant different $(P<0.05)$ in the different locations in temperature, $p H$, turbidity, dissolved oxygen, biochemical oxygen demand, chemical oxygen demand, lead, and zinc with values tabulated as follows; $26.00^{\circ} \mathrm{C}$ to $32,6.20$ to $9.20,0.21$ to $1.40 \mathrm{NTU}, 2.29$ to $5.85 \mathrm{mg} / \mathrm{L}, 5.24$ to $10.5 \mathrm{mg} / \mathrm{L}, 38.25$ to $64.26 \mathrm{mg} / \mathrm{L}, 0.12$ to $0.25 \mathrm{mg} / \mathrm{L}$ and 0.42 to $0.75 \mathrm{mg} / \mathrm{L}$ respectively. There were no observed significant difference $(P<0.05)$ in mercury and cupper. Some of the quality parameters evaluated had values higher than the tolerant levels established by WHO and FEPA and this calls for caution. There is need therefore, to bring to an end to the indiscriminate discharge of untreated effluent into the rivers through the law enforcement agencies (FEPA guidelines).
\end{abstract}

Keywords: Effluent, discharge, river, physicochemical,

\section{Introduction}

Water is an important natural resources, which touches on the lives of every living thing. Interaction between water and human activities are so pervasive that water is considered as a vital element in socioeconomic development (Umeham, 2014).

The quality of surface water is a primary consideration affecting it's utilization. In this view, the world health organization stipulated quality requirement of water for various applications (WHO, 1984). Water often gets polluted as a result of the activities of man in his everyday life. This indiscriminate use of water usually results in negative side effects such as eutrophication, increased incidence of water-borne diseases, organic and traces metal pollution, changes in species composition of aquatic biota and ultimately destruction of ecosystem integrity (Okoronkwo et al., 2013).

Ezemonye and Kadiri (2000), noted that in Africa, coastal water bodies are mainly polluted by run-off and industrial discharge. The discharge of industrial effluents had led to alterations in the quality and ecology of receiving water bodies (Umeham et al., 2012). These has resulted to challenges to both water resource managers, aquatic ecologists and hydrobiologists in the developing countries like Nigeria. It was recently in 1991 that an institutional steps were taken in Nigeria to regulate the quality of effluents that are discharged from waste generating industries into water systems (FEPA, 1991). The loads of pollutants discharged into water bodies are increased during the rainy season due to flood run-off and atmospheric precipitation. During the dry season, the action of wind becomes more pronounced in the transport of hazardous substances which bioaccumulates in land water bodies (Odiete, 1999).

The Nkuho river which is located in Umuchukwu Afara in Abia State and Nworie river which is located in Amakaohia in Imo State serve as sources of water for domestic uses including drinking, fishing etc. The cocoa-cola company discharge their effluents into the Nworie river whereas the saclux paint industry discharge their effluents into the Nkuho river respectively.

Studies have shown that water bodies of a river/stream is affected by the discharge of the effluents (Emiola and Olayemi, 1991). The findings of Sangodoyin, (1999) also opines that effluents discharge alters the physical, chemical and biological nature of receiving water bodies.

However, waste water treatments is not given the necessary priority it deserves and industrial/domestic waste are discharged into receiving water bodies without treatment (Ugbogu, 2010).

The consequence of this, is increased river pollution, loss of aquatic life and uptake of polluted water by plants and animals (Umeham and Okereke, 2005). These however, results to uptake of these objectionable substances into the human body causing health problems. The situation is compounded by the fact that the common man in most of these countries does not have access to portable water and in many cases, river water is used as a source of drinking water (Umeham, 2014). Therefore, the need to produce a data for the environmental protection agency and academic community is needed in the aforesaid rivers. This has necessitated the study. 
Study Area

\section{Materials And Methods}

The study area are Umuchukwu Afara in Abia State and Amakaohia in Imo State, all in Nigeria. The climate of Abia state and Imo state are of equatorial type. There are two seasons, rainy season and dry season. The rainy season starts from March and ends in November each year. Two peak of rainfall is July and September. The dry harmattan blows it's wind in December and January. The region consists of secondary rainforest which has been greatly subjected to deforestation and other human activities. the occupation of the inhabitants is mainly subsistence farming, yam, maize and cassava are the main crop, fishermen set traps and gill nets in the study stretch.

\section{Sampling Procedure}

Samples for the physicochemical analysis were collected in plastic container which were initially washed with detergent and rinsed with clean water. All the water samples collected were transported under cooled condition using ice cubes (in coolers) and analyzed in less than 24hours. The water samples were not treated with preservatives.

\section{Physicochemical Analysis}

The temperature was determined using the mercury - in- glass thermometer with $10^{\circ} \mathrm{c}-110^{\circ} \mathrm{c}$ calibration. The thermometer was inserted into each of the water sample until it stabilizes as described by (Nichollis, 2002).

The $\mathrm{pH}$ was measured directly using a $\mathrm{pH}$ meter (Jenway model) while the turbidity was measured using the method of Umeham et al., (2012). Dissolved oxygen was determined using Wrinkler's method according to Wetzel and Likens (1991).

Biochemical oxygen demand was determined using 5 days incubation method described by APHA (1985) while the chemical oxygen demand was also determined by same method of APHA, (1985).

Heavy metal content was determined by the Atomic Absorption spectrophotometry (AAS) described by Udensi et al., (2009).

The absorption was measured at a wavelength of $560 \mathrm{~nm}, 325 \mathrm{~nm}, 750 \mathrm{~nm}$, and $520 \mathrm{~nm}$ for mercury, copper, zinc and lead respectively.

Statistical analysis

Data obtained were analyzed using the analysis of variance (ANOVA) and the difference among means at the 5\% level were determined by the least significant difference test (lhekoronye and Ngoddy, 1985).

\section{Results And Discussion}

Table 1: Physicochemical Parameters Of Nworie And Nkuho River At The Upstream Station

\begin{tabular}{lllll}
\hline Parameters & $\mathrm{A}$ & $\mathrm{B}$ & WHO & LSD \\
Temperature & 28 & $26.00^{\mathrm{ab}}$ & $25-28$ & 7.66 \\
$\mathrm{pH}$ & $6.20^{\mathrm{ab}}$ & $6.40^{\mathrm{ab}}$ & -8.5 & 0.10 \\
Turbidity & $1.40^{\mathrm{a}}$ & $0.83^{\mathrm{b}}$ & 5.06 & 1.57 \\
Dissolved oxygen & $5.85^{\mathrm{a}}$ & $5.40^{\mathrm{a}}$ & 5.0 & 1.52 \\
Biochemical oxygen demand & $6.40^{\mathrm{c}}$ & $5.28^{\mathrm{c}}$ & 4.0 & 1.72 \\
Chemical oxygen Demand & $48.82^{\mathrm{b}}$ & $42.56^{\mathrm{c}}$ & - & \\
\hline
\end{tabular}

Means with different superscript along the same row are significantly different $(\mathrm{P}<0.05)$. Values are triplicate determination of sample.

\section{A $=$ Sample collected from the upstream of Nworie river}

$\mathrm{B}=$ Sample collected from the upstream of Nkuho river

From the table in 1.0, the mean temperature recorded a lower value in Nkuho upstream location (B) with the value of $26^{\circ} \mathrm{c}$. This means that the station is pollution free hence that it agrees with the report of WHO (1996). The value of sample (B) is very low compared to that of Nworie river. The difference could be attributed to the climatic conditions of the two river locations (WHO, 1996). There is also a significant difference in the mean temperature at $\mathrm{P}<0.05$ degree of freedom. Using the general tables of 1.0, 2.03 .0 , respectively. The $\mathrm{pH}$ values ranged from 6.20 to 9.20. There was a significant difference in the $\mathrm{pH}$ values. The mean $\mathrm{pH}$ of coca-cola effluent (E) was 9.20 which is above the recommended level of the World Health Organization (WHO, 1984) for domestic water use. It contributes significantly to the acid-base characteristics of the receiving river of the downstream of Nworie. This created a threat of alkaline pollution for domestic use. 
Table 2.0: Results Of The Physicochemical Parameters Of Nworie And Nkuho River At The Downstream Station When It Mixes With The Effluent

\begin{tabular}{lllll}
\hline Parameters & $\mathrm{C}$ & $\mathrm{D}$ & WHO & LSD \\
Temperature & $30.00^{\mathrm{a}}$ & $29.00^{\mathrm{a}}$ & Ambient & 4.32 \\
$\mathrm{pH}$ & $7.60^{\mathrm{a}}$ & $6.51^{\mathrm{ab}}$ & $6.5-8.5$ & 2.07 \\
Turbidity & $0.28^{\mathrm{c}}$ & $0.26^{\mathrm{c}}$ & - & 0.13 \\
Dissolved oxygen & $2.29^{\mathrm{b}}$ & $2.40^{\mathrm{b}}$ & 5.0 & 1.48 \\
Biochemical oxygen demand & $5.24^{\mathrm{c}}$ & $5.50^{\mathrm{c}}$ & 4.0 & 1.53 \\
Chemical oxygen Demand & $40.75^{\mathrm{cd}}$ & $41.80^{\mathrm{c}}$ & - & 2.11 \\
\hline
\end{tabular}

Means with different superscript along the same row are significantly different $(\mathrm{P}<0.05)$. Values are triplicate determinations of sample.

C $\quad \Rightarrow \quad$ Sample collected from the downstream of Nworie river

D $\quad \Rightarrow \quad$ Sample collected from the downstream of Nkuho river where it mixes with the effluent from saclux paint.

Table 3.0: Results Of The Physicochemical Parameters Of Effluents From Cocoa-Cola Company And

\begin{tabular}{llll}
\multicolumn{3}{c}{ Saclux Paint } \\
\hline parameter & $\mathrm{E}$ & $\mathrm{F}$ & WHO \\
Temperature & $32.00^{\mathrm{a}}$ & $31.00^{\mathrm{a}}$ & $25-28$ \\
PH & $9.20^{\mathrm{a}}$ & $6.62^{\mathrm{ab}}$ & $7.0-8.5$ \\
Turbidity & $0.21^{\mathrm{dd}}$ & $0.34_{\mathrm{e}}$ & - \\
D.O & $3.83^{\mathrm{ab}}$ & $4.23^{\mathrm{ab}}$ & 5.0 \\
B.O.D & $10.15^{\mathrm{a}}$ & $8.28^{\mathrm{b}}$ & 4.0 \\
C.O.D & $38.25^{\mathrm{e}}$ & $64.20^{\mathrm{a}}$ & - \\
\hline
\end{tabular}

$\mathrm{E} \quad=\quad$ Effluents sample from coca-cola company

$\mathrm{F} \quad=\quad$ Effluent sample collected from saclux paint

D.O = Dissolved oxygen

B.O.D $=$ Biochemical oxygen demand

C.O.D $=\quad$ Chemical oxygen demand.

The turbidity values ranged from 0.21 to 1.40 NTU. There was a significant different in turbidity values. The coca-cola effluents had the lowest turbidity value (0.21). This may be attributed to low concentration of particles and turbid materials disposed to the site. The highest value of 1.40 NTU obtained at upstream of Nworie river could be as a result of the high rains during the rainy season which could carry suspended solids from point sources and non-point sources into the river (bollkin and Keller, 1998).

The dissolved oxygen (D.O) ranged from $2.29 \mathrm{mg} / \mathrm{L}$ to $5.85 \mathrm{mg} / \mathrm{L}$. Significant differences also exist in the D.O. High temperature reduces the amount of dissolved oxygen, lowering the capacity of water to degrade oxygen demanding waste (Ugbogu, 2010).

The microbial degradation of organic matter determined as BOD was significantly different in their BOD values which ranged from $5.24 \mathrm{mg} / \mathrm{L}$ to $10.15 \mathrm{mg} / \mathrm{L}$. The mean BOD values of both the upstream and downstream of Nworie and Nkuho rivers were above the water quality standard for domestic purposes (E.U, 2010) which ranged from $4.0-4.5 \mathrm{mg} / \mathrm{L}$. The deviation could be attributed to the presence of industries and farmlands. Chemical oxygen demand values ranged from 64.20 to $38.25 \mathrm{mg} / \mathrm{L}$. There was a significant difference in the COD values. The COD obtained in the coca-cola effluents are $38.25 \mathrm{mg} / \mathrm{L}$ and $64.2 \mathrm{mg} / \mathrm{L}$ from the saclux effluents show the reasons for low dissolved oxygen (Okafor, 1988).

Table 4.0: Results Of The Heavy Metal Contents Of The Rivers And The Effluent Respectively

\begin{tabular}{|c|c|c|c|c|c|c|}
\hline Parameters & A & B & $\mathrm{C}$ & D & $\mathrm{E}$ & $\mathrm{F}$ \\
\hline Mercury & $0.09^{\mathrm{a}}$ & $0.06^{\mathrm{a}}$ & $0.07^{\mathrm{a}}$ & $0.05^{\mathrm{a}}$ & $0.04^{\mathrm{a}}$ & $0.06^{\mathrm{a}}$ \\
\hline Lead & $0.25^{\mathrm{a}}$ & $0.18^{\mathrm{a}}$ & $0.23^{\mathrm{a}}$ & $0.12^{\mathrm{ab}}$ & $0.14^{\mathrm{ab}}$ & $0.19^{\mathrm{a}}$ \\
\hline Zinc & $0.75^{\mathrm{a}}$ & $0.49^{\mathrm{ab}}$ & $0.45^{\mathrm{ab}}$ & $0.42^{\mathrm{ab}}$ & $0.39^{\mathrm{ab}}$ & $0.58^{\mathrm{a}}$ \\
\hline Copper & $0.45^{\mathrm{a}}$ & $0.41^{\mathrm{a}}$ & $0.38^{\mathrm{a}}$ & $0.32^{\mathrm{a}}$ & $0.29^{\mathrm{a}}$ & $0.34^{\mathrm{a}}$ \\
\hline
\end{tabular}

Means with different superscript along the same row are significantly different $(\mathrm{P}<0.05)$ and values are triplicate determinations of sample. Sample A to F are described in the table 1.0, 2.0, 3.0 respectively.

Among the heavy metal analyzed at various sampling location, were mercury, lead, Zinc, and Cupper. Mercury $(\mathrm{Hg})$ values ranged from $0.04 \mathrm{mg} / \mathrm{L}$ to $0.09 \mathrm{mg} / \mathrm{L}$. There was no significant difference in the mercury values. These values were higher than the value of $0.03 \mathrm{mg} / \mathrm{L}$ reported by Obasoham and Ovansaya (2000) for Ogba river.

The lead values ranged from 0.12 to $0.25 \mathrm{mg} / \mathrm{L}$. There was a significant difference in the lead values. Like cadmium, lead and it's compounds are present in municipal and industrial wastes and are transported into urban rivers through flood run-off water (Sandtoyani, 2013). 
Gasoline serving stations and high vehicular traffic are also sources of lead which get into inland water bodies through atmospheric precipitation. Lead values in effluent is lower than lead values reported for Ikpba river by Aguzie, (1999).

The zinc values ranged from 0.39 to $0.75 \mathrm{mg} / \mathrm{L}$. The concentrations of zinc in effluents and rivers are higher than those of other metals. However, there was a significant difference in zinc values. The mean values of zinc in the upstream and downstream of the two rivers and effluent are higher than the zinc value $(0.121) \mathrm{mg} / \mathrm{L}$ reported in Ikpoba river by Aguzie (1991).

The copper values ranged from 0.29 to $0.45 \mathrm{mg} / \mathrm{L}$. There was a significant differences in the copper values. The mean values of the copper in the rivers and effluents are higher than the mean copper value $(0.055 \mathrm{mg} / \mathrm{L})$ record by Oguzie and Igwegbe, $(2007)$.

\section{Conclusion And Recommendations}

The study revealed that Nworie and Nkuho rivers are under pollution stress due to point and non-point sources discharged resulting from industrial and domestic sewage (Thompson, 2009).

The physicochemical parameters evaluated show some values going higher than the WHO, (1984), WHO, (1996), FEPA (1991), SON tolerant levels for domestic water use. The deterioration of the surface waters can be minimized if the responsible government agencies ensures regular monitoring and strict adherence to the guidelines of Federal Environmental Protection agency. The discharge of effluents into body of water without treatment should be punishable by law of the Federal Republic of Nigeria. Industries without the requisite waste treatment plant should be made to shutdown. Regular monitoring of the Nworie and Nkuho rivers will be an added advantage, and awareness campaign needs to be carried out by government and non-governmental organizations.

We therefore, recommend an additional research to be carried out in these two rivers in the microbiological standard of Nkuho and Nworie river.

\section{References}

[1]. APHA (1985). American Public Health Association Standard Methods for the Examination of water and waste water. Washington D.C $15^{\text {th }}$ ed.

[2]. Botkin, D.B., and Keller, E.A (1998). Environmental Science. Earth as a living planet. John Wiley and Sons Inco. New York pp. 416-436.

[3]. E.U (2010). Water is for life. How the water framework directive helps safeguards Europe. Resources 28pp www.ecoLABEL.Ew Assessed, 2014.

[4]. Ezemonye, L.N., and Kadiri, M.O (2000). Bioremediation of aquatic ecosystems, the African perspectives (a review paper). J. Env. Rev. 3(2): 137-147.

[5]. FEPA, (1991). National guidelines and standards for environmental pollution in Nigeria. P. 238

[6]. Ihekoronye, A.I., and Ngoddy, P.O. (1985). Integrated food science and technology for the tropics. Macmillan Edu. Ltd Ibadan P. 346

[7]. Nichollis, R.J (2002). Analysis of global impacts of sea level rise. A case study of flooding. Physics and chemistry of the earth. 27:1455-1466.

[8]. Obasoham, E.E., and Orensaye, J.A.O (2000). Heavy metals in water sediment and some commercially important fish species from Ikpoba River in Benin city, Nig. J. Appl. Sci. Envi. Mgt. 4:263-268.

[9]. Odiete, W.O (1999). Environmental physiology of animals and pollution. $1^{\text {st }}$ ed. Diversified Resource Ltd, Lagos. P. 261.

[10]. Oguzie, F.A (1999). Contribution of industrial effluents to the heavy metal load of the lower Ikpoba river in Benin city, Nigeria. Afri. J. Appl. 2:60-63.

[11]. Oguzie, F.A., and Igwegbe, A.O. (2007). Heavy metal concentrations in water and three west Africa cichlid fishes of Ogba River in Benin City. J. Field Aquat. Studies. 3:41-48.

[12]. Okafor, N. (1985). Aquatic and waste microbiology $4^{\text {th }}$ ed. Dimensional Pub. Co Enugu, P 119.

[13]. Okoronkwo, C.U., Ogwo, P.A., Nwachukwu, O.N., and Etusim, P.E. (2013). Impact of grazing on bacteriological properties of Aku stream, Abia State Nigeria. J. Phy Env. Safety. Vol 3, No 1. 112-120.

[14]. Sangodoyim, A.Y. (1991). Groundwater and surface water pollution by open refuse dumping in Ibadan, Nigeria. J. Discovery and Innovations. 3(1). 24-31.

[15]. Sandtryani, N (2013). Groundwater pollution. Buzzle. http://www.buzzle.com/article/groundwaterpollution.html. assessed June 2014.

[16]. Thompson, M. (2009). Water is the essence of life. http://Euriearticle.com!?expert=maxThompson, Assessed May, 2013.

[17]. Udensi, E.A., Ukwu, F.C., and Isiguzo, J.N (2007). Antinutrients factors of vegetable cowpea (sesquipedalis) seeds during thermal processing. Pak. J. Nutri. 6(2): 194-197.

[18]. Ugbogu, O.C (2010). Environmental microbiology. $1^{\text {st }}$ ed. EBW Publishing Co. Pg 94-107.

[19]. Umeham, S.N (2014). Water is life, water is death ... an ultimate resources. $17^{\text {th }}$ inaugural lecture series of Abia State University Uturu.

[20]. Umeham, S.N. Avoaja, D.A., and Onuabuchi, I.A. (2012). The physicochemical status of Ibii stream, Aku-okigwe, Imo State. Nig. J. Env. Sci. Policy Evalua. Vol. 2. No 1, 12-78

[21]. Umeham, S.N., and Okereke (2005). Some aspects of the limnology of Iyi Ogbighe, a stream impacted with refined petroleum products in Isuikwuato L.G.A of Abia State, Nig. J. Health and Visual Sci. Vol. 7, No. 2

[22]. Wetzel, R.G., and Likens, G.E (1991). Limnological analysis. $2^{\text {nd }}$ ed. Springer - Verlago Pp. 391.

[23]. WHO (1996). WHO and World Health Organization: Guidelines for drinking water quality. Health criteria and other supporting information. Geneva.

[24]. WHO, (1984). World Health Organization: Guideline for drinking water quality. Health criteria and others information Vol. 2. Geneva P. 306. 